\title{
The Future of the Torpedo
}

\section{Vice-Admiral P. H. Colomb}

To cite this article: Vice-Admiral P. H. Colomb (1897) The Future of the Torpedo, Royal United Services Institution. Journal, 41:238, 1465-1489, DOI: 10.1080/03071849709416090

To link to this article: http://dx.doi.org/10.1080/03071849709416090

$$
\text { 曲 Published online: } 11 \text { Sep } 2009 .
$$

Submit your article to this journal

Џ Article views: 8

Q View related articles $匚$ 


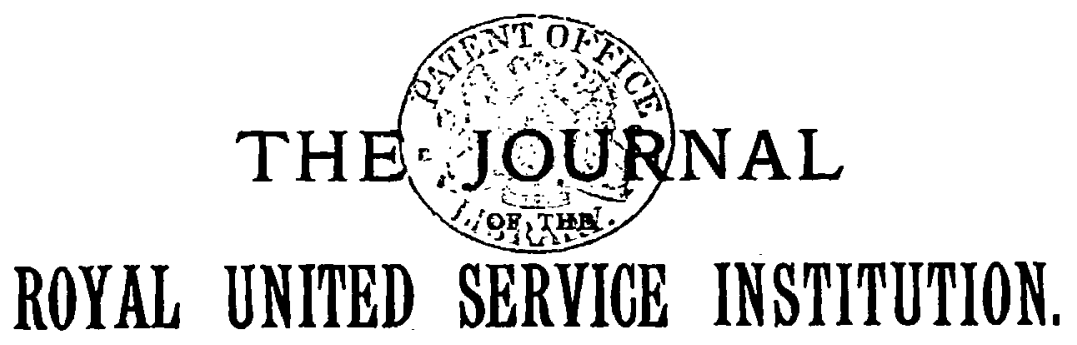

\begin{tabular}{lll}
\hline VoL. XLI. & DECEMBER, 1897. & No. 238. \\
\hline
\end{tabular}

[Authors alone are responsible for the contents of their respective Papers.]

THE FUTURE OF THE TORPEDO

B. Vice-Adminal P. H. COLO.MB.

'Tuesday, June 8th, 1897.

The Right Hon. The Earl of Hopetoun, G.C.II.G.

(Paymaster-General), in the Chair.

IT is peculiarly the function of this Institution to watch all changes in the material with which it is intended to carry on future war, to discuss their nature and character, and to endeavour to forecast their exact meaning.

Except in the open arena of this thentre, it is difficult to suggest where such a function-of such immense value to the State-can be usefully exercised. All those who have been concerned in the production of new elements of force, or in the modification of old ones, have natural and proper prejudices in favour of the new descriptions of material. . All who have been officially concerned in introducing the material into the Naval or Military Service, are somewhat apt to look on it as a father on a child, and surround it with an atmosphere of affections and antipathies which must be supposed in some degree to warp the judgment. Then, on the other side, there are great bodies of men who are directly concerned in maintaining the status quo of the old material, or who are committed to a group of opinions which rest upon the slatus quo. -The largest body of all is that inert but powerful mass of men who take things as they find them, without examining their foundations, without watching their growth or shrinkage, and without applying the critical faculty to the investigation of their relations to their environment. This body will accept, without noticing it, a series of small changes, all in one direction, and tending to one inevitable result. It will even accept a vOL. XLI. 
rery great change, so long as no one points out what such a change involves, and so long as the incongruous ideas surrounding the old and the new do not come into strong contact and collision.

Now there is no place where all these mental forces can so well meet, and break, and eddy, as tributaries to a great stream of sound thinking, as in this beautiful theatre, at last worthy of the important discussions destined, let us hope, for a long time to come, to take place within it.

: Here all ideas have frec course, and can be uttered with that full frecdom which feels itself bound by the limits of decorum, and is first of all bent on giving every man his duc.

There is one particular body whose voices are conveniently heard here, which I notice last. This is the body which, being independent alike of responsibility for production of new material, or for its introduction into the Services, has employed itself to the best of its powers in the office of independent critic. The individuals composing this body' may be, and generally are, diverse in their views. Many of them have been forming view; through a long course of years, secing, or fancying they see, in the history of the material of war, certain fixed principles which always govern; belicving that principles are so unswerving in their action that the application of them cnables the users to forecast the future, and to show that matcrial productions intended for use in war are now on the right track, and will go on to produce certain momentous results; and now, on the wrong track, pursuing a path which must be ultimately retraced.

There are other individuals of this body who do not so much concern themselves with underlying general principles. 'They are more impressed with the nature and immediate infuence of any striking change in the material proposed for future war, and are less apt to look at the general environment of the change than on the results of the change itself.

In effect, we get from the one section of these independent critics a certain -almost fixed hypothesis of the nature and character of war, into which they endeavour to fit, as time goes on, the new developments of material, and to discover whether they are of a permanent or of a temporary character. From the other section we get an enthusiasticand, of course, often a prophetic-support of material changes, the pressing forward and universal adoption of which becomes the be-all and end-all of their advocacy.

Both scctions necessarily make mistakes. Their wisdom consists in the speed and readiness with which they admit them. The man of hypotheses has, sometimes, not yielded in time to the enthusiast's prophetic instincts; he has not modified his lyppothesis to the full extent demanded by the new material production. The enthusiast pursues and upholds the object of his enthusiasm after some new introduction has-to use a familiar but expressive phrase-put its nose out of joint.

Placing myself, as I believe I ought, amongst the first group of independent critics, I have noticed it being given as an instance of the irony of fate that I, who have now for more years than I like to look back 
upon, been the steady upholder of the battle-ship as a fundamental element of naval war, should be the one to declare her position precarious.

But no framer of hypotheses on the facts before him is very good at his trade, if he is not prepared with plausible methods of wriggling out of one hypothesis into another.

I might take Bcnedick's vicw of the situation, and say that when I supported guns and armour in the battle-ship, as against the torpedo in the unarmoured torpedo-vessel, I did not thinl: I should live to support the torpedo-ressel against the battle-ship.

But I need not really go so far. It is on clear record that for more than twenty years I have always believed, and said I beliered, that a type of battle-ship, heavily but partially armoured, of great size, with two or four heavy guns in barbettes or turrets forward, or forward and aft, was not a permanent type-that such a vessel did not, in fact, fit into the war hypothesis, and was really incongruous to her environment.

I have, in fact, ever since the present type began to show itself in the "Devastation" and "Thunderer," looked for a change to a battleship of much smaller displacement, having a larger area covered with - lighter armour, and carrying at broaldside armament of more numerous and lighter guns.

-It may be said that the change is at least somewhat long in coming. But whether I regard the general thought of the Navj, or whether I address myself to the expression of that thought in the decreasing size of the heavy guns, to the increasing areas of thinner armour, or with more interested ardour to the growing development of the line-of-battle cruiser, I gather additional reasons for adhering to the gencral hypothesis put forward in the Prize Fssay of 1877 .

Thus I must assume myself to have held that in no case, and quite apart from the torpedo, was there stability in the type of battle-ship at which we have arrived. And $\mathrm{my}$ convictions on this head are greatly strengthened by the existence of a law which any student of the progresis of material science in the Navy must have observed in existence, that is, that perfection is the sign of disappearance. It was so with the sailing brigs; it was so with the sailing frigates; it was so with the sailing -line-of-battle-ships; it was so with the steam two-decker being superseded by such great steam frigates as the "Orlando" and "Nersej.". It was so with these, by the appearance of the "Warrior"; and when we arrived at the very perfect "Achilles," or, in some senses the more perfect "Hercules," it was merely the signal that the building of that type had come to an end.

It is pretty clear on the face of things that the existing type of battle-ship has now reached its prime, under the commanding genius which has had her development in charge. Sir IVilliam White has brought the existing battle-ship to such a state of completeness and perfection as the embodiment of current naval idea, that even he might be puzzled to suggest further advances on the same lines.

That fact then, is, according to the routine history of naval material $4 \mathrm{w} 2$ 
during the present generation, a warning to us to look for some momentous change.

I bring this general conclusion of my paper thus into early prominence, because it is the status of the present battle-ship which is most brought into question by the development of the material of torpedo warfare. The type being already threatened by the general condition of things apart from the torpedo, it appears to me that the development of the material of torpedo warfare, pure and simple, will, in the first place, hasten the coming change, and in the next direct its course and determine what the character of the hattle-ship of the future is to be.

For I can by no means abandon the hypothesis which has stood the test of actuality ever since naval war took a distinct form, namely, that there must be a battle-fleet for claiming and maintaining the command of the sea. This battle-fleet I have ever held, and hold still, must be composed of vessels such that they cannot be matched except by similar vessels, and that superiority will lie-all other things being equal-with the fleet $\underline{\text { hich }}$ is most numerous.

I do not yet profess to know what this type will be. I am only convinced that we shall very shortly cease to build any more of the present type.

$F$ do not expect to carry many minds with me at this first onset. I rather suspect my conclusions may secm to most of us preposterous. That is always the case where one has for a long time been following up a particular train of ideas, and the conclusion is amnounced to those who have not kept company by the way. But for myself, I cannot get over the arguments as they stand, nor escape from the conclusions towards which they point.

I well recollect, in the year I travelled down to. witness the experimental firing at the "Glatton's" turret, in company with some of the members of the committee which had been to Pola to examine the earlier developments of the "Whitehead torpedo," their caution in expressing any sense of what it might mean. Their expression was that it did what it professed to do, but whether this meant any change in the system of inaval warfare, or, indeed, whether there was any opening at all for the weapon, they would not go so far to express as an opinion.

But it went on. It was placed in gun-ships as if it were itself a gun of immense power, but of very short range and somewhat uncertain trajectory. "It was a sort of glorified carronade where the greater destructiveness was balanced by the shortness of its range and its bad shooting; and it was possible to debate over its real value on somewhat the same lines as our forefathers had debated over the large-calibred short-ranged carronade, with the small-calibred great-ranged 'long' gun."

About the destructive power of a torpedo, when successfully exploded, no one could doubt. Even with the charge of $60 \mathrm{lbs}$. of guncotton, which was that of the earlicr weapon, few ships could sustain the explosion and live. Some arrangements of bulkheads and coal stowage under water, air spaces, and barriers might in cases prevent the exploding torpedo from doing fatal injury. But I belicie from the first it has never been suggested 
that anything in, or attached to, the hull of the ship herself, could act in the way that armour acts against shot, in rendering a portion of the ship's bottom impervious to the blow of a torpedo. The only attachment which has been at all relied on has been the system of nets set out some 30 feet from the hull. But such an arrangement was inapplicable to ships under way, and the torpedo was left without any practical hindrance by way of resisting defence.

'Ihe torpedo was first introduced into gun-ships simply' as a different class of gun. Had it remained in this situation it would not necessarily have affected the type of war-ships. Neither the weapon nor its machinery was of any great weight, and generally speaking it was more a question of space than of weight if many training torpedo-tubes were introduced.

But it appeared that it must have a distinct effect on tactics. The gun was already capable of gaining the victory in action, even of destroying the ship it was opposed to. 'There was a general belief that in the result of rifled shell guns, as against steel and iron hulls, whether armoured or not, their destruclive powers were very much greater than those of smooth-bore shot guns had ever been against the wooden hulls to which they were opposed. The introduction of the torpedo into ships carrying such guns was, in a sense, a work of supererogation. It was a weapon not really wanted, and it seemed as though in the cnd it would be rery little used.

To the superior gun-ship there was an unpleasant equality with the inferior gun-ship introduced, if she allowed herself to get into torpedo range with such a ship. Indeed, the equality was like to be overbalanced in such a case, for the superior gun-ship was probably the larger ship, and therefore offered the better mark to the smaller ship's torpedo. The larger ship, on the other hand, was as liable to be sent to the bottom if struck as the smaller one, while there was no inherent increase of accuracy in the larger ship's torpedo fire. Taking it altogether, therefore, the tactical policy of the superior gun-ship would be to begin, continue, and end the fight with the inferior gun-ship, well out of range of the torpedo.

There might have been for the inferior gun-ship an opposite tactical policy. Just as it was the policy of the superior gun-ship to avoid a position which would lessen her superiority, so it might be the policy of the inferior gun-ship to strive for a situation which might lessen her inferiority by bringing her torpedoes into play.

If we follow this line of argument up we might see that, as in all cases force is a question of money, so the pressure of the facts might give rise to the building of smaller ships where gun-power was sacrificed to speed, and where the torpedo was relied on as the principal weapon. The tactics of such ships would have been to use their superior speed so as to get within torpedo range of the superior gun-ship, which would be unable to frustrate the attempt, as she had given up speed to retain superior gun-power.

But such a-development as this, coming directly from the nature of the case, and perhaps logically its outcome, was altogether too bold to bc 
considered. ITe rarely see such things happening in the history of naval material. We must always expect a long period of - incongruity going on, where the old things and the old systems are incongruously and illogically maintained, side by side with the new things or the new systems, which are silently supplanting them. Men never at first perceive the final results of a new development. Even when they begin dimly to foresee, a natural instinct causes the mind to revolt against being led into an unknown and doubtful sea of speculation; and usually the nature of the change is not perceived until it has been instinctively accomplished.

So that we could scarcely anticipate a change coming about in this way. It was more likely that we should look at the torpedo as an auxiliary weapon to be used, like the ram, only on some special occasions. It would be maintained as a weapon of primary importance because of its cnormous power of destruction, but of secondary importance because it could so seldom be brought into play. It would be supplied, to a greater or less extent, to every ship in a battle-fleet; but battle-flects in action would be compelled, because of the torpedo, to fight at great range, and therefore the torpedo would never come into play.

The general and more immediate result, therefore, of the introduction of the torpedo was to push the ram back, and to bring the gun forward as the decisive weapon, without making any appreciable change in structure or in the differentiation of naval force. 'The great cievelopment and improvement of the torpedo thus had no manifest effect. It was more than met by the increase in the power of the gun, weight for weight. There was greater range, flatter trajectory, better mounting, greatly increased rapidity of fire. The torpedo as an ausiliary weapon in a gunship did not promise to have much effect.

But it was curious to note that whereas in this and other countries many authorities were found to uphold the proposition that the ram would beat the gun, and that the ramming battle was the battle of the future, no authority, so far as I am aware, either here or elsewhere, has pre-figured the torpedo-action pure and simple as the battle of the future. But those who faroured the idea of the future ram-battle are obliged to admit that the torpedo makes against it.

Alnost from the first it was scen that an ordinary stenm. pinnace, carrying a torpedo on each side ready for launching, was a full match for the most powerful and costly war-ship ever heard of, if only she could get within the 200 or 300 yards of her which limited effective torpedo range. The American Civil War had familiarised the naval world with ideas of secret and silent night altacks, using explosives against the sides of too secure and careless adversaries. The locomotive torpedo offered an almost infinite ficld for this sort of warlike ingenuity and daring, and the. thoughts of all were full of it. There is some difficulty in tracing cxactly the connection of idcas between this particular form of attack and the construction of light and fragile vessels to carry it out. I do not recall clearly whether any reasoned demand for such a vessel as the "Lightning" was the cause of her construction, or whether, being constructed on an outside and instinctive view of the situation, she became the cause rather 
than the effect of naval views. Here she was, however, as far back as 1877 , only three or four years after the torpedo itself had secured a position. She was fragile in hull beyond the dreams of naval architectare. Displacing 27 tons and being 74 feet in length, she was too large to be called a boat and too small to be called a ship; but she could discharge a missile capable of destroying any ship afloat at a blow, and she possessed the then enormous speed of 19 knots an hour.

Apart from her whole meaning, whatever that might be, the "Lightning" was the pioneer of new developments in the matter of speed. Almost ever since the introduction of the screw propeller, specd and displacement had been so closely associated, that down to the date of the "Lightning's" appearance we did not look for higher speed unless there were greater displacement. It was, indeed, almost a received axióm that high speed could only be got on a large displacement; and, if I am not mistaken, size was increased on purpose to get speed.

The general result puzzled the critics who rested their hypotheses on historical analogy. In the old wars, the lighter frigates had the greater speed, and the heavier battle-ships the less speed, so that fighting force and speed were interchangeable. Now the ships which had less fighting force had less speed also, and the tactical balance was upset.

It is true that, long before the "I,ightning," Sir Edward Reed had made a vigorous push to force the speed of the smaller displacement, but practically it was long after the "Iightning's" time that we began seriously to throw over fighting force in the smaller displacement in order to exchange it for speed. It is almost the arrangement of yesterday that left the speed of the battle-flect at 17.5 knots, while raising that of the attendant frigate to 20 knots.

The result, no doubt, has been that the critic with his lyjpothesis founded on the principles drawn from listory and experience is, so far, "no longer troubled. It has come about, as he was bound to think it would, that the old balance is restored, force-that is, gun-power and armoured protection-being made to give way, speed takes its place, and the lesser force has the greater speed, and the greater force the lesser speed, just as it had a century ago. But the disturbing novel elenient of the torpedo remains behind.

The restoration of the old balance has come about without pressure on the part of the torpedo. There is no direct connection between the torpedo, and the fixing of the speed of the 14,900-ton battle-ship at $17 \cdot 5$ knots, and of the 7,350 -ton cruiser at 20 knots. That change has been a differentiation of naval force, brought about by the gun alone, and, therefore, probably caused by the same agencies that in former days produced the slow line-of-battle-ship and the fast frigate.

But the "Lightning" showed more clearly than ever before what could be done when gun-power was wholly sacrificed to speed. She was the .smallest and the fastest ressel afloat; and if she could bring her weapon into operation there was not really a more powerful vessel existing. She was 27 tons, and yet, supposing the conditions admitted it, she was a match for the "Alexandra," 350 times her size!. 
What meaning were we to attach to such an unprecedented element of naval force? What did the "Lightning" mean? Did she mean to the dominant naval nation the same thing as to the sub-dominant? Was she a threat to British naval power, or did she cnhance it? How was British naval power going to fit her into its policy and programme? The new vessel had certain disabilities. She was scarcely sca-going. She was certainly not sea-keeping. To use the phrase which her type gave rise to, her "radius of action" was short. She could not operate at any great distance from her mother-port. How then could she be used for that system of strategy which made the enemy's coast-line the frontier of the dominant naval power's territory? According to the hypothesis set up by. the experience of naval war, the moment the dominant naval power was forced into defending her own coast-line and ports, she, ipso faclo, ceased to be dominant. The "Lightning," so far, was a reserve vessel, only to be brought into use by the British when they had been beaten off their platform of dominant naval nation, and were forced to allow some-other Power to take that command of the sea which they could not hold.

There was a natural, and not improper, reluctance to provide for this iñner line of defence when the outer line was notoriously insecure. It was illogical to declare for the command of the sea, to decline taking the steps necessary to secure it, and at the same time to make preparation for losing it. Hence the "Lightning" was slow to take hold as part of the British naval system.

But, for sub-dominant nations, the role of the "Lightning" was clearer. Costing a mere trifle, exposing to hazard the lives of not more than a dozen or fifteen men, and yet being a solid threat against the life of a battle-ship costing three-quarters of a million of money, and against the lives of the five or six hundred men embarked in her, the new vessel was eminently qualified to prevent the blockade of her mother-port by battle-ships, and to compel all ordinary war-ships of her enemy to keep their distance. All the Continental nations forthwith began to build multitudes of improved "Lightnings." They were generally larger, with greater specd, and with longer radii of action, as a consequence of increased coal supply and improved economy of consumption. Their force was also increased by additional torpedo-tubes, and a larger reserve of torpedocs.

Not altogether willingly, England, in 1878-9 built a few improved "Lightnings." Ripening opinion claimed that long before Great Britain could be driven to use the new torpedo-boats in defence of her home ports, she must have been on her knees suing for an ignominious peace.

But it scemed out of keeping with progress that so novel an idea as the "Lightning" should be lost to this nation; meanings for her were sought which were scarcely in the minds of those who designed her.

As a threat to gun-ships under way watching a port, it was absolutely necessary that the torpedo-vessel should have very high speed. If she had not the power of coming to close quarters with the battle-ship or cruiser, she was no threat at all. If she was to threaten a battle-ship or 
cruiser squadion in the open in daylight, her possible speed of passing from gun-range to torpedo-range must be very great indecd. She must calculate on running through the fire of the gun-ships with such rapidity: as to preclude fatal damage before she discharged her torpedo. If her shot was successful, she would not expect to sustain much more fire; if it was unsuccessful, the high speed would be useful in taking the vessel out of fire as quickly as possible.

Acting from a port against a squadron at sea, the whereabouts of which might not be easy to discover at night or in thick weather, the high speed might be a necessity, if discovery was to be made at all before day broke. But on the other hand, if the approach was to be secretly made, and the object was to steal alongside and discharge the torpedo before discovery, the high speed would not be available. Every consideration would prompt low speed. There would certainly be noise in high speed which was not present in low speed. As to visibility, it was certain that the foam at the bow mould show out to an extraordinary extent in darkness; and this could only be kept down by low'speed. There was an inherent defect in the earlier boats of an immense bright flame from the funnel at high speed, which absolutely forbid its use when the approach was to be made by stealth.

A good many of these considerations lost their force, if a "lightning" was to be employed in a different way. When the attack was to be made by a "Lightning" on gun-ships at anchor in roadsteads and harbours, and not on ships under way in the open sea, many of the conditions demanding speed were absent, and generally those compelling slow speed were paramount. It must be expected that a careful look-out would be kept, not only from the ship -it was intended to attack, but also from all possible points in the vicinity from which the approach of torpedo-boats might be descried. It would be imperative to do nothing which at night might cause early discovery. The approach must be inaudible and invisible, and this could only be secured.by the loviest possible speed. The theoretical point was made clear in practice by the conduct of the "Lynch" and "Condell" in destroying the "Blanco Encalada" under these conditions. "The two ships coming from the South, took care to aroid any out-look which might probably be kept in their direction, by passing Port Caldera, where it was supposed ships of the Congressist Fleet were lying, far at sea, and ultimately approaching it from the North, whence their appearance would not be expected. Then skirting the North shore of the bay close under the land at slow speed, they cautiously approached the South shore under which the "Blanco Encalada" was lying. Both ships kept at low speed, and the "Condell" had fired her second torpedo before she put any speed on. The "Lynch" following in like manner, kept her speed down till the second discharge of her torpedo took effect, and the "Blanco Encalada" began to sink, The high speed of these ships-each 20.2 knots-was, therefore, not a necessity for the attack made; not being even very necessary for the sea voyage previous to the attack, as Huasco, whence the torpedo gun-boats issued on their mission, was only 80 miles south of Port Caldera. It 
may possibly have brought them off with the minimum of damage. But I suppose if we were to make accurate experiments and calculations, it would be found that the safety, even the rapidity, of escape after firing a torpedo in a 15-knot and in a 25 -knot ressel would not be found to differ in any very marked degree-the intervals of time dealt with in either case being so very small.

But the "Lightning"-an extraordinary torpedo-vessel of very high speed-was upon us, and if we, as the dominant Naval Power, were precluded from adopting her as sub-dominant naval nations readily and logically did as the defeider of home ports, some employment for such a class of vessel which was consistent with our position, ought to be found.

It was supposed to be found in the now somewhat despised secondclass torpedo-boat. These boats were smaller "Lightnings." They were 60 feet long, they weighed only 15 tons; they steamed only 15 or 16 knots, but they carried two torpedo-tubes and could be hoisted into and out of battle-ships almost like any other boat. Their raison d'st/e was, that they could be carried off the enemy's ports on board the battle-ships, could be hoisted out and sent into the port, to approach it by stealth, and to fire torpedoes at the ships found inside, in what would necessarily be an indiscriminate manner.

The building of great numbers of torpedo-boats by- Continental nations, which were continually improving in speed and increasing in size, went on. Fingland distinctly, but I think quite logically, lagged behind in the production of these enlarged "Lightnings." Writers, who went no further than to count noses, steadily upbraided our Government for its slackness, and shook the increasing number of first-class and sea-going torpedo-boats abroad, in its face, as if it were obvious that the only answer for the dominant Naval Power was to build a greater number of the same class of torpedo-boats which the sub-dominant Naval Powers were producing.

The gradual extension of the radius of action of the torpedo-boat . began to change its raison d'ilre. It began to be.held that France especially, in building a class of "sea-going torpedo-boats" was developing the torpedo-boat attack on our ports, rather than the torpedo-boat defence of her own. But I suppose this kind of feeling did not arise till about eleven years after the "Lightning," when in 1888-0 France produced such vessels as the "Alarme," "Aventurier," "Défie," "Ouragan," etc., vessels 150 feet long, of 148 tons displacement, 20 knots speed, 40 tons of coal, four torpedo-tubes, and two 3 -pounders as gun armament. Our own boats of that date were shorter, smaller in every way, but were not deficient in speed, torpedo-tubes, or gun armament.

But considerable alarm had begun to spread through the Navy and into the offices at Whitehall, in anticipation of what these vessels on the other side of the Channel might mean to the war-ships in our more or less exposed anchorages, such as Spithead, Portland Harbour, and Plymouth Sound on this side. 
I think it was before this that authors on the Continent had begun to assert in various forecasting pamphlets, that the downfall of England would be effected by her obstinacy in adhering to the heary-armoured battle-ship flect, destined to be destroyed by the light and cheap, but overwhelmingly powerful, torpedo-boat fleet. Our attention in the Navy was more directed to what the open-sea defence of our battle-fleets might be against the open attack of the torpedo-boat fleet. The picture in our own minds was that of our battle-fleets, composed of large, heavilygunned, armoured battle-ships, not of excessive speed, behaving just as our sailing battle-fleets hacl done in time of yore, passing from point to point in the open sea, in assured superiority to evcrything clse, except a like fleet composed of greater number of ships. Or else we mentally contemplated the same battle-flect cruising off an enemy's port and supporting an inshore squadron which was closcly blockading it.

When the Continental pamphleteer defeated our battle-fleet by a fleet of torpedo-boats-off Cape Finisterre, if I recollect rightly-we were not disturbed. The answer was two-fold, and seemed conclusive. The torpedo-boats of the day had not the sea-keeping qualities necessary to kesp up a watching station in such a locality; althongh, normally, the specd of a torpecio-boat fleet was considerally greater than that of the battleship fleet, in reality it was very much less. If such an improbable attack could be carried out, the attacked battle-ship fleet would at once form line abreast, and, turning their sterns to the torpedo-boat flect, would keep them out of torpedo range, and subject to gun-fire until they were either destrojed, or abandoned a hopeless attempt.

If the attack by torpedo-boats were to be made by night, and by surprise, the answer was that, even in proximity to a port which it was watching, a battle-flect was not an easy thing to find at night. If it were found, the tactics arranged for daylight would be such a bar to the success of the torpedo-boat fleet that it was not possible to conceive sustained attempts of the sort. In any case, too, in reasonable weather, lying watching an enemy's harbour and depending on reports of the inshore squadron as to - any attempts of the enemy to put to sen, the ships of the battle-ship fleet might lie with their nets down and steam at short notice, and thus practically defy the torpedo-boats' approach.

II. Gabriel Charmes' book was translated into English in 1886. He did not believe, it will be remembered, in the vitality of the large heavilyarmoured and heavily-gunned battle-ships. 13ut I think he rested the anticipated disappearance of the battle-ship more on the advance of the light, but heavily-armed, gun-boat, than on the advance of the torpedovessel pure and simple. He, was, for instance, entirely against enlarging the torpedo boats. He declared that the 45 -ton torpedo-boat of 33 metres in length was "a thorough sea-going vessel, and fit for any voyage." And, speaking of the 71 -ton 45 -metre boat, he said there would be nothing to complain of if the "pattern were adhered to, and were the limit, instead of the beginning, of increase of size."

All MI. Gabriel Charmes' views on the future of naval war, as well as those of his patron and supporter, Admiral Aube, were coloured by a 
disbelief in every lesson of the past, and an idea that all things had become new to the modern Navy. It was chiefly there, where, in my judgment, these authorities failed. At any rate, the views did not hold either in the French or the English Navy. Fnglish naval authorities, and English naval officers generally, continued to think, that at sea at least, the place and ' $r$ lle of the large, heavily-gunned, and heavilyarmoured battle-ships was secure.

The state of our fleet at the moment is the most complete and convincing exhibition of this view.

Sundry experiments had assisted to keep us in this frame of mind. Actual trials at sea had shown how much nearer the measured-mile speed of the gun-ship or vessel was to her sea-speed, than was that of the torpedo-boat, even of the largest and most approved patterns. Attempts on the part of the French in their manœuvres to combine a torpedo-boat squadron with a gun-ship fleet in strategical and tactical autumn manouvres became complete failures on the part of the torpedo-boats. It was even found that many of the boats could not discharge their torpedoes in a sea-way.

So far, then, as operations in the open sea were concerned, the torpedo-boat, and the torpedo with her, notwithstanding the increasing power, range, and accuracy with which it was being endued continuously, fell back in naval estimation.

But one thing could not be ignored, namely, the threat, already alluded to, as to what the new sea-going torpedo-boats across the Channel would certainly do, in war, to the exposed war-ships in fairly open anchorages on this side. The threat was strengthened by the fact that invention had to some extent, at least, deprived us of the defence against torpedoes that nets had formerly afforded.

In naval circles in general, the opinion was largely held that France might go so far as to make her declaration of war by a wholesale destruction of battle-ships and cruisers lying in port and unwarned of the torpedo disaster that was impending.

It was most remarkable that we ourselves formed no designs of opening a war in such a way, nor did it seem to occur to us that in this case what was sauce for the goose was sauce for the gander. We were, it may be said, so entirely occupied in considering the defence of our ships and ports against the enemy's torpedo-boats that we gave no thought to what our own first-class torpedo-boats might do across the Channel in the same way. It even seemed possible that, as Charles Dickens said of another kind of thought, this one was "busy on our lips, but idle in our heart."

Yet without any doubt the fear of this kind of thing began to take hold of us and to grow in 1882, and has been growing and strengthening ever since.

While no doubt some of the reasons for the growth have been drawn directly from the autumn mancuvres; while the officers in the gun-ships have uniformly and almost unanimously maintained the futility of torpedoboat attack by stealth and surprise on properly prepared and watched. 
ships; they have admitted the tremendous anxieties and the sleeplessness that must invade every pillow in a gun-ship flect exposed to torpedo-boat attack at night.

The officers who have commanded the torpedo-boats .conducting these mimic attacks almost invariably tell a different story. They declare generally that the officers in the battle-ships and cruisers, large and small, have misapprehended; that when physical objects, booms, obstructions, and barriers do not surround the gun-ship and actually prevent the torpedoboat's approach, her fate is sealed by the attack of torpedo-boats during the hours of darkness in suitable weather.

This fear of attack while at anchor has most naturally spread to a fear at sea and under way, and I am not at all sure that the officers who have accepted this fear restrict it to the hours of darkness.

The idea that a modern battle-ship might not be the acme of naval force which the ancient sailing battle-ship was, was put forth some time ago. If my memory serves me, it was put forward by Sir Nathaniel Barnaby about the "Inflexible" time, and before the torpedo-boat was such an acknowledged danger to the battle-ship as she has since become.

In 1882 Captain (now Rear-Admiral) IIarris, in a paper read to the Institution, when I had the honour of being in the chair, followed this up by distinctly avowing that it was necessary to attach to every battle-ship sea-going torpedo and gun-boats of great speed. These vessels were to be in part protective of the battle-ships, but more in the way of adjuncts to her, making up for her deficiencies. There was no broaching of the idea that a type of ship requiring such adjuncts could not be a permanent one.

In my remarks upon the paper, I said I thought it was one which in - a year or two would be referred to as giving a starting-point to the policy of the future. I was not as yet prepared "to desert the simplicity of the old serried rank of ironclads, one astern of the other, for making a solid attack."

- Early in 1883 Mr. (now Sir Nathaniel) Barnaby read a paper, entitled "Battle-ships-a forecast," in which he said that, " The use of torpedoboats of high speed and in great numbers, tends to the gradual extinction of attacking or blockading the sca-ports of an enemy by means of large ships, because of their great cost, and the risk of fatal blows from the torpedo." Again he said that, "The battle-ship of large size is not only likely to become obsolete for the attack and blockade of ports, but also for another important-service, viz., harassing the commerce of the enemy." He secmed to think that the battle-ship, to act as such, required much modification, and he apparently deprecated a tendency to increase her size and cost.

Captain Harris followed this up a couple of months later by a paper, entitled," Maritime "power and its probable application in war." $\mathrm{He}$ drew forcible attention to queries put in Mr. Barnaby's paper, and while admitting that they could not be answered off-hand, he yet hoped that discussion following his paper might draw towards the proper answers. 
He distinctly doubted whether it would be sound policy to build few battle-ships of great nominal power and size, and contended that their position would be rendered insecure, were they to be opposed by greater numbers of lighter gun-ships. It might not be quite wise, he thought, to look so far ahead, but he could not but ask whether ten battle-ships of the first class were the equals in action of five such ships combined with fiftecn or sixteen protected torpedo and gun-vessels, all of equal speed and of the same equivalent value.

So far as the paper dealt with battle-ships, it rather supported the idea of supplementing them by vessels of different types than urged the idea of abandoning the type for something else. Captain Harris had, in his former paper, made sure of the growth of the torpedo-boat into the sea-going and sea-kecping torpedo-vessel, but there was nowhere as yet on this side of the Channel any admission that the position of the gunship was likely to be threatened decisively by the advance of the torpedo-ship. The gun-battle-ship would still hold her own at sea, and would fulfil her own functions when supported by adjuncts of suitable character.

But as the general fear of the torpedo-boat grew, and took the form of apprehending attack on ships at anchor in open ports and roadsteads, two methods of relief suggested themselves :-First, and less firmly, the idea advanced of so protecting harbours containing men vof-war that torpedo-boats could not enter them ; and secondly, but much more firmls, grew the idlea that something special ought to be done to prevent an - enemy's torpedo-boats from putting to sea at all.

The result was that while plans for protecting our home ports were considered, a new class of vessel called a "torpedo gun-boat" was produced in 1886- $\tau$. The "Rattlesnake," "Crasshopper," "Sandfly," and "Spider" were launched. These were vessels of 525 tons, 200 feet long, intended to steam 19 knots, with coal enough to carry them 2,400 miles at 10 knots. Their gun armament was one 4-inch gun and six 3 -pounders, and they had two torpedo-tubes. These vessels were not considered wholly satisfactory" after trial, and in 1888-9 improved "Rattlesnakes" were produced in the nine ressels of the "Sharpshooter" type. They were rather larger and intended to be rather faster than their forerunners, and the armament was modlified in the direction of fewer and heavier guns and increased torpedo power. They were of 735 tons displacement, and were again followed up in 1892-3 by elesen ships of the "Jason" class of 810 tons, with the same gun and torpedo armament as their predecessors and without any nominal increase of speed. The last developments in this direction are the five ships of the "Dryad" class, which have increased in displacement to 1,070 tons, with an increase in coal capacity and armament, but without an increase of speed, and with a reduction in torpedo power.

Now; although other ideas may have crossed and re-crossed the designs of these twenty-nine peculiar vessels, it seems clear enough that they must all have been intended to fill the role of the inshore squadron in a modern blockade, with special relation to the sealing-up of torpedo- 
boats in their own ports. Their small size would enable them to creep close in to the blockaded port at night, which would be the time chosen for an enemy's torpedo-boats to put to sea. Their guns would especially threaten such vessels, while their torpedoes would be an even more complete threat to any larger vessels attempting to pass out. 'Iheir general sea-keeping qualities would enable them to persevere in this service, to draw off as daylight broke each morning, and to close the port as darkness fell at night.

For this particular duty it did not appear that very great excess in speed was necessary. Obviously, they ought not to have been slow vessels, because then torpedo-boats might have run past them with a sense of impunity. But it was to be supposed that an enemy desiring to send torpedo-boats to sea would think twice of letting them run the gauntlet of five or six, or perhaps eight or ten, of these vessels, which might be able to keep them for a considerable time under fire, and were bad marks for their own weapon-the torpedo.

The vessels came to be called "torpedo catchers," being corrupted from "torpedo-boat catchers." It was a bad name. It led to a general sort of belief that they were designed to chase and overhaul torpedoboats in the open sea. They have, I believe, never been tried in their rôle of inshore watchers, but they have been tried and have been understood to fail in the role for which they could scarcely have been designed, namely, as torpedo-boat chasers in the open sea.

'At any rate, those who were best acquainted with the management of torpedo-boats were loudest and strongest in their scorn of these ressels as anti-torpedo-boat agencies. They claimed that if the enemy's torpedoboats were to be suppressed, it must be done by a class of vessel which was only a superior sort of torpedo-boat. There was much newspaper correspondence of a more or less anonymons character, but disclosing very strong fecling amongst the officers who were qualified torpedo men. The sense of the Admiralty was reached, and nine or ten torpedo-boats of greater size than usual were produced in 1893-4. While the largest boats of 1889 were 130 feet long and of 85 tons displacement, with 23 knots speed and 20 tons of coal, the $1893-4$ boats were 140 feet long with 130 tons displacement, $23 \frac{1}{4}$ knots speed, and 25 tons of coal.

These vessels were so far a concession to the torpedo officers' demands for torpedo-boats to suppress torpedo-boats, and they had a gun armament of three 3-pounders, doubtless intended to be emplojed on this service.

Immediately afterwards a great step was taken, when orders were given for the construction of forty-two vessels of an entirely new class, named "torpedo-boat destroyers." These vessels, of which the "Havock" was the earliest complete example, werc from 180 to 210 feet long, and displaced from 220 to 277 tons. They. steamed at the rate of from 27 to 29 knots an hour, carried 50 to 70 tons of coal; an armament generally of one 12-pounder and five 6 -pounders, with a crew of fortytwo to fifty men; and they had two or three torpedo-tubes. 
The intended construction of these ships was announced in the First Lord's statement in 1893-4, and the earlier specimens of the class-the "Havock" and "Hornet," by Messrs. Yarrow-were tried in the early spring of 1894. The "Havock" was the first tried. She carried 60 tons of coal, which was estimated to take her 4,000 miles at 10 knots. That implied sea-keeping qualities approaching those of the latest types of battle-ships, and very much greater capacity than any of the so-called " torpedo catchers," now called first-class gun-boats, none of which have more than 2,800 miles of coal endurance. On the measured mile this vessel ran 26.78 knots, and for three hours over 20 knots an hour. Her total cost was $£ 34,254$.

On the 23rd of February, 1894, the sccond of the class, the "Hornet," was tried, and she ran the speed up to 28 knots.

In Lord Brassey's "Naval Annual” for 1895, Mr. Laird-Clowes, who is almost always excellent in the accuracy of his facts, gives none of the fifteen specimens which had been tried when he compiled his tables, less speed than that of the "Havock"-26.78 knots. All the rest show over 27 knots, and the fastest of them-the "Boxer"-rises to 29.31 knots.

Here we must note the remarkible sase that is before us.

England has never directly or consciously threatened the battle-ship of the type which she herself has been the author of, and has upheld. She has hated and scouted the threat to her type of battle-ship which the steady progress of the torpedo-boat has developed. She has been all along most grudging of her assistance toward developing torpedo-boat warfare, and has more than any other nation devoted herself to developing the torpedo as the auxiliary weapon of the gun-ship. Her development of the battle-ship has followed historical analogy in sacrificing speed for fighting force with the gun as the weapon, and she has steadily turned her back equally on the exaggerated threatenings of a Gabriel Charmes, and on the more sober invitations to discussion emanating from Sir Nathaniel Barnaby and Admiral Harris.

And what has been the end of it all? She has been the author of the most tremendous attack on the position of the battle-ship which has yet been delivered, and she has done it in a sort of simplicity of heart, as in the belief that she was strengthening and guarding the position of her own splendid creations - the battle-ships of to-clay:

In France, for instance, there was nothing like the "Daring." Her highest class boats were but improved torpedo-boats; with the disabilities attaching to them, which enabled us to smile at the hypothetical destruction of our fleets by the pamphleteer, and at the more measured warnings of M. Charmes when he pointed out that sixty torpedo-boats only equalled the cost of one battle-ship. The greatest displacement of any of the French sea-going torpedo-boats was under 150 tons; the highest speed was no doubt in two cases set down at 30 knots, but there was no such thing as a group of $27-k$ not boats, while 40 tons was the extreme coal stowage, and the faster boats carried under 20 tons.

We have seen how the idea of the torpedo-boat becoming the master of the battle-ship by attack in daylight in the open sea, took root, 
flourished, and withered. It withered simply because the then torpedoboat had neither the speed nor the sea-kecping qualities which were necessary.

Then followed the stage when it was universally admitted that the torpedo-boat ats it stood was a port-guard of great potency against the advance of battle-ships. She was not admitted to be a gencral threat to the battle-ship, and the batlle-ship was held to be as necessary as ever for the blockade of a port. The idea was to stupplement her-not to abolish her-by something which had a tinge of protection in it, but was chiefly to be an enhancement of the battle-ship's power.

Then came the growing and intense fear of the torpedo-boat attack on ships in port, to be guarded against by provision of shelter harbours and blockades of torpedo-boats. We arrive at the admission that in wartime a battle-fleet clare not lie in an exposed anchorage-must be sheltered by piers, and chains, and booms. It is made quite plain that the only expenditure in works at Gibraltar as to which the Navy as a body is really anxious, is the provision of a close harbour where battle-ships and cruisers may rest in security and where anxious fuars may be respited.

Then we, who are the leaders in this announcement of fear, produce a vesscl which cannot suffer from such fears, and promises to keep the sea and lic in exposed anchorages in the immediate vicinity of the masses of the enemy's torpedo-boats.

A something has been produced which does not fear anything but its ditto. It has'means of escape open to no other vessel, and is capable of facing, when in sufficient numbers, any type of existing battle-ship. In such an attack the safety of the battle-ship used to be her speed. She has iltogether lost that superiority. In smooth water the torpedo-boat destrojer beats her by about 10 knots an hour.

There only wanted the one crowning admission to complete the position. "The prime use of torpedo-boat destrojers," says Captain Sturdee, in the Prize Essay for 1894, "is to destroy the enemy's boats, and they' are now attached to fliets for the protection of the batlle-ships."

Thus England, which has occupied the highest place in asserting the stability of the position in war to be taken ${ }^{-b}$ battle-ships of vast dimensions, heavily gunned and armoured, has become the foremost nation in denying that stability:-(1), by declaring provision of shelter harbours an absolute necessity; (2), by declaring that battle-ships at sea require the protection of torpedo-vessels; and (3), by producing a type of torpedo-vessel which must be more completcly able to face the battleship than anything ever heard of before.

Her battle-ships have 17t knots speed; her torpedo-boat destroyers can overhaul them at the rate of 2,000 yards-good gun range-in six minutes.

She can put twenty-five of the destroyers ifloat for what it costs her to put one battle-ship alloat. If she thinks of sending battle-ships and destroyers into action, she will only expose the same number of lives in fifteen destroyers that she will expose in one battle-ship.

That is the whole position :

vol. XLI. 
It seems to be either of two things:-(1), that the whole theory of the battle-ship 'being a something which can only be matched at the same cost by her ditto-is an idle dream; (2), that the destroyer is at present the battle-ship.

It is plain that fifteen destroyers acting together cannot now be matched, at the same cost, by anything else afloat. If it is still doubted that they would easily master one battle-ship in the open sea in broad daylight, it will scarcely be doubted that no one battle-ship would willingly attempt to drive them off the sea.

'Then, how are we to speak of battle-ships commanding any' sea, when it is a necessity for them to shelter in close harbours at night, and, therefore, to leave the enemy's torpedo-ressels in command of the waters they have quitted in fear of their lives? You cannot be in command of a sea and not in command, in the alternate hours of daylight and darkness. If you can keep the command of the sea in the hours of darkness, you can, because of that command; anchor your flect in unprotected anchorages. To speak of command of the sea co-existing with the necessity for a walled-in port, is a contradiction in terms. If the latter is to be at necessity in future, command of the sea in future must be a mere remembrance.

I do not believe-I cannot believe-I never have beliused-in compromises with principles. Such things exist, ruund and intact, or they do not exist at all; modifications of the principle on which the idea of a battle-ship rests may come about, but the principle will be killed by the modifications. Command of the sea may be modified, so that a battleflect lying in an open anchorage, has it in daylight, and loses it in darkness. But the principle of command of the sea is lost in the modification.

Look at it another way. France and our own country become silly cnough to quarrel, and to go to war; France, not depending vitally on her seaborne commerce, closes it, and devotes herself to the destruction of ours. Our main object is to keep French war-ships off the sea, and shut up in their ports; and Brest is one of those ports which we are most anxious to blockade. We are told that we cannot send a battlefleet off Ushant as we used to do, unless we send a fleet of torpedo-boat destroyers with it, to protect it. That is to say, we fear the French torpedo-boats in a way we do not fear the French battle-ships. Must not the converse prove true? Must not the French battle-ships in Brest fear the destrojers we propose to send over more than they fear our battle-ships?

Is not the conclusion incvitable? France will not send her battle-ships to sea, because of our destroyers off the port. We shall not send our battle-fleet to sea, because their work was being done by another force-the destrojers.

Suppose there are twenty battle-ships in Toulon, and our command in the Mediterranean depends on our ability to overawe them and keep them in port. We could not overawe them by sending twenty-five battle-ships off the port, because we acknowledge that these twenty- 
five dare not challenge the torpedo-boats at Toulon. They are more afraid of the torpedo-boats than they are of the battle-ships. If it were not for the torpedo-boats they could lic watching quite comfortably at Madalena, in only an eager hope that the enemy might come out. Norr they dare not. But they look to an occasional night's rest when they have raised the blockade, and gone to Gibraltar's close harbour to get some sleep.

But supposing we never sent a battle-ship near Toulon, but despatched thither a feet of destroyers. Have we not then lifted the wet blanket of fear off our own shoulders, and cast it over the shoulders of the twenty battle-ships? Is it possible to imagine the French bringing out their battle-ships to defeat our destroyers? Is it not certain that they will employ some other form of vessel?

There is a considerable margin to work upon in the torpedo-ship. The torpedo-boat destrojers are not reported to be everything that is perfect. But a ressel which costs the twenty-fifth part of the cost of the battle-ship, and only exposes one-fiftetnth of the number of lives, may cvidently be made larger without greatly reducing her torpedo-force. She may be improved in speed, in sea-going and sca-kceping qualities without greatly reducing the numbers which can be put on one battleship with advantage. Already we are preparing for a 33-knot speed to match the increased speed of the latest battle-ships. Already an armoured torpedo-boat destrojer has been sent to sea. MIust we not reasonably expect directly, the perfectly armoured torpedo-vessel; sea-going; sea-keeping; comfortable to live in; and with 7 or 8 knots more speed than any possible armoured gun-ship of present type $\vec{r}$

Captain S. Earuley-IVIL.Mot, R.N. (Retired):-On hearing this remarkable paper I do not know whether my feelings were more of admiration at the able way in which the arguments were marshalled before us, or of wonder at the conclusions at which the author had arrived. I suppose there is no person who has studied naval history with greater care than Adniral Colomb, arid one of his conclusions is that when a type of ship has reached perfection it generally disappears. He observes that when the sailing-ship was brought to its greatest efficiency, it gave place to the wooden steam vessel; that when we gradually brought that to a high pitch of perfection in those splendid two and three deckers, such as the "Duke of Wellington" and the "Duncan," they also disappenred and gave place to the ironclad. As the "Warrior" and many other successors are obsolete, he therefore views with apprehension our present type of battle-ship as likely to disappear also. It appears to me, however, that during that period from $18 B 0$ to 1880 , we were more or less in the experimental stage. We hat produced various types, atnd were not sure whether the broadside ironclad like the "Warrior," or the turret-ship like the "Devastation" was the best. 1ype. But in the present rissel it appears to me we have found the lappiest combination of both types. We have in vessels like the "Royal Sovereign" and "Majestic:" buth the turret-ship and the broadside ironclad combined. We latve put in them the best features of both classes, and it appears to me that this latest phase of battle-ship construction has come to stay. Adniral Colomb afirns that we must hold command of the sea, but sees in the future that command held by an improved lorpedo-ressel. The arguments which to his mind seem to lead towards this conclusion are that the gun-ship is afraid of the torpedoboat, and that because the batlle-ship sceks the shelter of booms and under certain 
conditions has to be guarded at sea against this particular form of atlact, hence she loses command of the seat, which has, therefore, passed to the ressel of which she is afraid. Such reasoning may be carried too far, and is not altogether borne out by history. One instance only I will give, and that is the period of fire-ships. There was no doubt that the battle-ships of those day's were very much afraid of the fire-ship. It was a great dianger to them. Well, what was the effect of that? It did nol do awas with the sailing battle-ship and lead to the fire-ship being the embodiment of uaval force. It simply led to methods being adopted of overcoming the diunger, and one of the principal methods was that of ships sailing in line, by which they could more easily get out of the way of the fire-ships. This led to the gradual disappearance of the fire-ship. Then, again, there is a slight flaw in the reasoning as regards the protection of fleets at sea and also the antidote against torpedo-boats. It has been often stated that the "Rattlesuake." class were built specially to overcome torpedo-boats for the protection of fleets at sea against their attacks. That was not the case. $A$ s soon as torpedo-boats were seen to be a valuable adjunct to harbour defence, it was considered also desirable if possible to utilise them for scatgoing purposes. If they could accompany fleets and be effectively used in action, they would constitute a serions danger to the ships. But experience had shown that the torpedo-boat was not capable of keeping the sea. The torpedo officers, therefore, demanded something which could keep to sea, but of the smallest possible dimensions, in which would be its principal defence. At first there seemed a difficulty in producing such a craft, and vessels of 1,500 and 1,6 ') toas-like the "Scout" and others-were built. That they were actually intended to be used like torpedoboats may be assumed from the fact that they were to have elevein torpedo-tubes. As they did not fulfil the requirements-being too large-and as the French were building such a craft of about 350 tons, our contractors produced the "Rattlesnake," of j00 tons, which it was considered would be able to accompany fleets to sea and, under cover of smoke in a flect action, make the attack with the torpedo. Well, Admiral Colomb sees in some form of torpedo-vessel the future representative of naval force. The destroyer is to him an alarming fact; but he also sees that the command of the sea cannot be held by a vessel of 300 tons, and, therefore, he forecasts an enlarged torpedo-ship, an armoured vessel with very high speed, 7 or $\mathbf{S}$ knots higher than the ordinary typs. What is the result of this reasoning? The result is that such a vessel to possess these attributes must approach in dimensions to a battle-ship or large cruiser, and then, whilst you have been enlarging the torpeilo-vessel to this ideal craft which is going to command the seas, and drive the battle-ship off them, you have produced at craft which is herself vilnerable to the attack of the destroyer. ${ }^{1}$

Captain H. J. MaY, C.B., R.N.:-Admiral Colomb has given us a most thoughtful and historical lecture, but I fail to see in looking at the historical part that we are, as he seems to think, in the presence of something very new. He has traced with great care the development of the destroyer. He traces the rise, so I gather, of the clestroyers from the "Lighining," of some 40 tons, and now he tells us that the destroyers are 230 to 270 tons, whereas before the building of the destroyers the nearest thing to them was the French torpedo crati of 150 tons. The destroyer's speed is 97 to 30 knots, and some of the French boats had already

1 Though not foreseeing in the developinent of the torpedo the disappearance of the gun-ship, I consider this weapon the principal dauger to the latter, and that it is not sufficiently recogrnised. The great effect of the torpedo, if successfully applied, is a strong arguinent against excessive dimensions of battle-ships, and in favour of a greater number of noderate-sized vessels. The torpedo has, however, had little influeuce upon construction, the tendency being either to ignore it altogether, or, as Pepys said, "to fortify ourselves, and not be ashamed." -S. E. W. 
a nominal speed at any rate of 27 knots. I cannot see, therefore, that we are face to face with a strikingly new craft. Admiral Colomb himself has told us most forcibly the disabilities of the old-fashioned craft. First and foremost, they could not keep the sea ; secondly, their radius of action was exceedingly small; and, thirdly-I do not think Admiral Colomb touched upon this point, but it is a fact of which he knows well -they are most terribly vulnerable. The whole of the engines and boilers of a torpedo-boat present a mass of tubes and gear which the very smallest fragment of a shell will shatter, and thus put the vessel out of action; and the destroyers, seeing that their engines and boilers are much bigger, and therefore casier to hit, are far more vulnerable in this respect than the torpedoboat. If Admiral Colomb had brought forward any facts as to the sea-keeping powers of the destroyers, then I think we might have thought that we should have to look at things afresh; but he has not done so, and, so far as I know, the destroyers have not proved the thorough sea-keeping craft that some of their designers-hoped they would. At the present noment, if you go down to our ports, you will see a procession of destroyers going out in the morning; and you will see the same procession of destroyers coming in at night. At any mic, they are not exereised at keeping the sea; and, as a rule, we exercise our craft at anything they can do. Therefore, I doubt extremely whether we are going to send a flect of destroyers to blockade Brest; and, if we did, whether the French would be afraid of them. Instead of the first gale of wind being, as it always was in the old days, an opportunity for the British craft to show their sea-kecping qualities and the excellence of the training, the first gale of wind would send at least three-quarters of the destroyers awaty from theit stations-if not into harbour altogether. Then is the destroyer of no use? I do not think so. I consider that under certain conditions the destroyer can help the battle-ship, and under other conditions much more likely to occur, the battle-ship may help the destroyers. In the matter of keeping the sea, the battle-ship, or other ship of the escorting type, such as the big cruiser, can help to make life bearable, if not comfortable, to the men on board the destrojers; whilst, I belicve, in the stress of action experience sill finally prove that the destroyer, or similar craft, will be able to help the battle-ship by rushing into short iange of the encmy and discharging her torpedoes when a favourable opportunity occurs. Indeed, I cannot see that because we have developed the destroyer we should do away with the battle-ship, or, conversely, if we stick to the battle-ship, that we should do away with the destroyer. I believe they are both useful to each other, and that we should retain them both.

Captain A. A. C. PARR, R.N. : -I must apologise for rising to say any word at all, because till this morning I did not know the subject of the lecture. It struck me that in the final conclusion of the lecturer, where he says that the type of vessel which he would adveate would be a latger and a protected torpedo-vessel, there might be some little difficulty in saying what the best type would be. If the torpedoes are to be carricd above the water and are to be protected, the amount of armour will have to be considernble. When a considerable amount of armour is carried, of course the size of the vessel has to be very considerably increased. Unless the torpedoes are well protected they are liable to be damaged by the shell fire from the guns of the ship that they are attacking, as well as the sessel herself. The engines also, of course, have to be well protected, as Captain May said, or they will be damaged by the shell fire, and the vessel will be rendered useless. If the torpedoes are to be carried under water then it also means that the vessel is to be of largy size, for space has to be found for the submerged tubes, and also in that case protection has to be found for the cngines, or else, as I said before, they are liable to damage. Now, if we come to very high speeds we come to some vessel more or less of the type of the "Powerful" and "Terrible," which are taken up almost entirely with boilers and engines, leaving very little space indeed for any number of submerged tubes. Two tubes a side, or even three, I suppose, would. 
not be sufficient for the type of ressel which the lecturer would adrocate, and, therefore, it seems a little difficult to know what the size of the vessel is to be, and if it is to be a large one. I have seen in the last few days several articles in the newspapers, some written without any knowledge of the subject at all, and others with more knowledge, but all rather saying that the gunnery in Her Majesty's ships is now at at low ebb, and that they are not capable of hitling-well, we will say a hay-stack-at very short range. Being in command of one of the battle-ships in the fleet and having carried out torpedo and gunnery practice quite recently, I may say that I do not think such a description is quite accurate, and that if we are given a large vessel to fire at the greater proportion of our shell will go into that vessel at a very considerable range; and unless she is very well protected indeed, before she comes within the range at which her torpedoes will be effective there will not be much of her left above water from which to fire them.

Major $A$. D. SEToN, R.A. :- $\lambda$ s a gunner who has an interest in naval tactics, it seems to me that the last.speaker has really hit the nail on the head. The matter appears to turn vary largely upon the question of Q.F. guns, which I think Admiral Colomb has not dwelt upon. Ite say's in the first page of his paper :- "I have, in fact, ever since the present type began to show itself in the 'Devastation ' and 'Thunderer,' looked for a change to a battle-ship of much smaller displacenient, having a larger aren covered with lighter armour, and carrying a - broatiside armament of more numerous and lighter guns." It seems to me that is the direction in which the development is more likely to take place thin in that of the present type of destrojer. I think most people who look ahead will agree with him to a very large extent, that the present type of battle-ship, as such, has probably approached nearly to perfection; bat the question arises whether the present type of torpedo-vessel, as such, has not also approached somewhat to perfection. The range of the torpedo is a very important item in this question, and from what I can learn it seems that there cannot, humanly speaking, be a much further developinent of range or accuracy in this weapon. It is at some disadvantages because of the element in which it moves, which in the matter of trajectory, visibility, and size, must always render it, as compared to a gun, a more or less unreliable weapon. Therefore, as the last speaker stated, the torpedo-vessel must come pretty close to make her torpedoes effective. Then the question of Q.F. guris comes in. The Times of the 7 th of June liad an account of the result of the last year's naval gun practice, in which it states that the average of twenty-one ships that fired fifty rounds and upwards in 1596 , with 6 -inch $Q . F$. guns, gave one hit to every four rounds, and with the $4 \cdot \bar{T}$, though the average was pulled down by some very bad scores, the practice of thirty-nine ships gave 29.7 per cent. of hits. The Times does not hold that up as being exactly good, but it seems, assuming that to be an average, without allowing for any improvement in material and training, such as sighting and so on, the matter of $Q . F$. guns will be a very awkwarl question for any unarmoured vessel to get over, if she is going to have one hit to every four rounds fired from 6 -inch shells and 29 per cent. of hits with $4 \cdot 7$, to say nothing of smaller guns. Unless she is very securely armoured there is very little chance of her getting near cnough to do any great amount of damage. As Captain. Eardley-Wilmot says, increase of size brings increase of visibility, and it also means slower speed in most cases. There is a great distinction between a difference of $S$ and 9 knots, between the speed of the torpedo-destroyer and the battle-ship, and a difference of something like 16 knots as at present; and it seems very doubtful if an improved destroyer can ever maintain this differenfe of speed. If you drop it down to $s$ or 9 knots a great deal of the advantage goes. The point we must look to is to hate ressels in the future somewhat of the class of the "Dupuy-de-Lome" that the French have built, with thinner armour and more of it. I do not think it has been quite appreciated what the effect of a continuous fire of shell is. It is not probable that any one will waste 
time pounding away with armour-piercing shot that can only carry at best dead metal into the ship, when they can explode a pound or two of powder in the same vessel in unarmoured parts.

Admiral H. Bors:-Although I consider myself obsolete on this question, many years ago, as my friends here know, it came especially under mydepartment as Director of Naval Ordnance. I have listened with pleasure to Admiral Colomb's lecture, and also to the remarks that have been made in the discussion. There is one point $I$ should like to emphasise in respect to the chances of success in $a_{-}$torpedo attack. I think the article in the Times this morning or yesterday, in respect to the naval gunnery, is unsatisfactory and misleading altogether, especially to outsiders. You will observe that in the results given, the hits only are reckoned. The size of the target is not given, the distance is not given, the speed is not given, the size of the ships is not given, the state of the sea is not given, and all sailors know the greatest possible difference exists between gunnery practice from a large ship, and from a machine going fast, like a torpedo-boat or any other small craft, as far as the motion is concerned. The ship may be practically steady, firing almost as from the land, when a small terpedo-cruiser or boat going at high speed would be in most cases moving violently, and it would be almost impossible to take accurate aim. This is an important point in favour of the ship attacked in torpedo warfare.

Admiral Colons, in reply, said:-The only object a retired officer can have in reading a paper of this kind is to stir up thought, to draw attention to a set of conditions which demand study and consideration, if our progress is to be even and continuous. One speaker mentioned my "advocacy" of something. I have not adrocated anything except study of the conditions. I believe that armoured torpedo-vessels will very' soon be produced. I do not advocate them. Speakers seem to forget my old clain that our right course is always a middle one. We cannot go on indefinitely deccloping the battle-ship at one extreme, and her greatest enemy, the torpedo-vessel, at the other. Either one or the other will disappear if a mean cannot be found between them. If the armoured torpedovessel is at hand, she will not. run to an extreme in armour, or in size, if she is to last. Captain Eariley-Wilmot used the fire-slip, as an illustration, telling against - the position I take up. I do not lose sight of her, but she enforces the lesson I draw. She disappeared because it was not possible to combine the two kinds of fighting. $\mathrm{My}$ position is the impossibility of combining the two kinds of fighting represented by the battle-ship and the torpedo-vessel. Captain May and Captain Sturdee have both done their best to show how the battle-ships and the torpedoboat destroyer may figlit in company; nothing has yet been done better than Captain May's work in this way ; but anyone studying these productions can only be struck by the extreme difficulty of combining the battle-ships and the torpedovessel in any flect action. I understood Captain May to say that there was no probability of the torpedo-boat destroyers being sent to blockade. I was a very elose student of the writings of torpedo officers that immediately preceded the advent of the to rpedo-boat destroyer. I submitted myself for two or three nights to the officers assembled in the smoking-room of the "Vernon," and I certainly understood that the vessel called for, and now produced, was intended almost wholly as a blockader. I presume that Captain May does not mean to say that in his view the battle-flect and the torpedo assistants might not be in the vicinity of the enemy's ports?

Captain IIN:-I think they can work in combination, but not the torpedo sepiarately, J

Admiral Colonb:--Directly that comes to pass we see an impossibility. At night you would be bound to fire from your battle-ships on every torpedo-ressel you saw. You would sink your own torpedo-vessels, as it is well known we so often did in the manceures; and the fear of doing so would cause you either to. take your battle-ships without torpedo-ressels or torpedo-ressels wilhout battle- 
ships into the enemy's waters. I think Captain Eardley-Wilmot's description of the reasons put forth officially for the production of the "Rattlesnake" class is correct. But then idens crossed and re-crossed, and if you look back you will see that we looked on their chief functions to be exercised in blockade. They are still better calculated for that service than for any other. Something las been said about gun practice. I did not in my paper go into the question of what the practice would be from a battle-ship upon an approaching torpedo-vessel. But I have worked out the attack of eight torpedo-vessels with an excess of 7 knots speed upon four battle-ships, and find that the time allowed for sinking or disabling them is surprisingly short, and it looks as though the torpedo squadron would be bound to have one of the battle-ships, even if seven of them were stopped or disabled.

\section{Captain MAY :-At night?}

Admiral Colons:-Broad daylight. What I want to put before you, and what I hope I have put before you and before the Service, is the general set of conditions, the way in which they are pointing, and the preparation that we ought to make to meet sudden changes nearing us. The more I have studied these conditions - and I should tell you that this payer has been delayed for a couple of years because I did not think the time was ripe for reading it-the more the conclusions of the paper have forced themselves upon me. They may not be true, but my object is gained if I can set the Service to consider closely the curious conditions at present surrounding us, and whether we are prepared for such changes as they portend.

The Chairyax (The Earl of Hopetoun):- I feel certain that everybody will feel decply grateful indeed to the Admiral for the very able and interesting paper which he has presented to the Institution. The paper is full of controversial matter. The discussion which followed, the reading of the paper has been controversial, and I feel that I myself am in some danger of being drawn into the controversy; but I think, seeing that I am an amateur speaking before experts, I had better be extremely careful, and merely confine myself to summing up in a very few words the contents of the paper and the opinions put forward by other gentlemen in support of their contentions. The Admiral has prophesicd an enormous, a stupendous, change which positively makes one's blood run cold to think of, because it entirely upsets all our preconceived ideas of naval warfare. He has told us that the battle.ship, as we know it, is to disappear, and that the gun is to be superseded entirely by the torpedoas a means of offence. He has traced in a most interesting manner the rise of the torpedo and the evolution of the torpedo-boat destroyer, and he has reminded us that in producing this wonderful vessel-the torpedo-boal destroyer-we have unconsciously put forward a very great threat against the existence of the battle-ship. But, gentlemen, granted that the battle-ship as we know her to-day is doomed, every poison has its antidote. We know that when shells made wood ships impossible, iron ships were produced, and they were covered with armour. When the torpedo-boat began to be regarded as a sericus danger, the Q.F. gun was produced. May it not be possible that at some future date an antidote may be found even to the torpedo-boat destrojer? The Admiral allows and affirms that a fleet of battle-ships of some kind or other will be necessary; the only question is:- of what type are those battle-ships to be? I do not suppose that anybody can contend that the present magnificent type of battle-ship which we have is for all time to be the embodiment of the sea-power of a great maritimg country. Science is too restless for that. We cannot hope to go back to those comfortable, jog-trot times when, for nearly 200 years, one particular type of vessel satisficd all the requirements of naval warfare. But the Admiral has also reminded us that when a type reaches perfection it generally disappears. I venture to remind him that it does not disappear all of a sudden. 
It disappears slowly and steadily, by various stages and modifications. It does seem as if we had come very near perfection in our present baltle-ships, because, if I may remind you, we have built, or are building, or are preparing to build at the present moment, close on thirty ships of almost the same type-1 mean the "Majestics," "Royal Sovereigns," and that class which is known as the "Canopus." There are small differences between them, but still, taking them generally, they represent one type of battle-ship, and it is hardly probable that our expert naval authorities would have ventured to back their opinion to the extent of nearly-thirty ships, unless they had been pretty nearly certain that they had reached what would be, for sone time to.come at any rate, perfection. However, gentlemen, there is very little doubt that we shall go on improving, and that modifications will take place, and it is possible that these modifications may be very much governed by the apotheosis of the torpedo. But whatever our opinions may be on this subject, whether we shelter ourselves belind the impregnable armour of the batlle-ship or whether we favour the triumphant torpedo, on one subject I feel certain that we entirely agrec, and that is, that our very warm thanks are due to the Admiral for his interesting paper. 